\title{
Renewable Energy in the Electricity Sector and GDP per Capita in the European Union
}

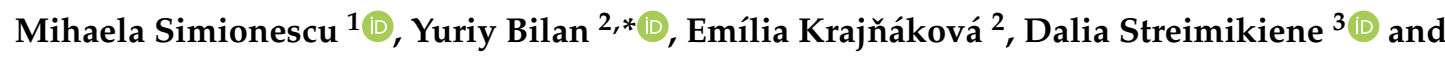 \\ Stanisław Gędek ${ }^{4}$ \\ 1 Institute for Economic Forecasting of the Romanian Academy, 050711 Bucharest, Romania \\ 2 Faculty of Social and Economic Relations, Alexander Dubček University of Trenčín, Studentska 3, \\ 91150 Trenčín, Slovakia \\ 3 Kaunas Faculty, Vilnius University, Muitines 8, LT-44280 Kaunas, Lithuania \\ 4 Faculty of Management, Rzeszow University of Technology, 35-959 Rzeszów, Poland \\ * Correspondence: yuriy_bilan@yahoo.co.uk
}

Received: 9 June 2019; Accepted: 29 June 2019; Published: 30 June 2019

\begin{abstract}
Considering that the European Directive has imposed that at least 20\% of the total energy should come from renewable energy sources (RES) by 2020 already and the specific targets for each European Union Member State, this paper attempts to assess the importance of GDP per capita in realizing these targets and also the effects of the RES share in electricity. Contrary to previous research, this paper does not consider the connection between economic growth and RES, but rather the potential connection between the share of RES in electricity and the real GDP per capita. The panel data models indicated to a positive, but very low impact of GDP per capita on the share of RES in electricity in the period of 2007-2017 in the case of the EU countries, except Luxembourg that has outlier values of GDP per capita. However, causality between the two variables was not identified. Some groups of countries were described according to these variables using cluster analysis. Future research should focus on the extension of this model by including other important variables such as RES potential available in the countries with specific geographical conditions.
\end{abstract}

Keywords: renewable energy sources; electricity; GDP per capita

\section{Introduction}

In the last few decades, concerns about environmental security, sustainability and climate change have grown, forcing governments to find viable alternatives to the traditional energy sector to limit its negative impact on the environment. The use of renewable energy, even if expensive, reduces gas emissions that negatively influence the environment [1-3]. A world agreement has established the reduction of greenhouse gas emissions by $80-90 \%$ by 2050 [4]. Moreover, considering that fossil fuels will be depleted relatively soon, the reform of the energy sector has been considered a priority for the European Union (EU) and other regions of the world too. A potential solution to all these issues could be represented by the growth of renewable energy sources (RES) not only in energy consumption, but also in energy production [5]. Today's technologies are used to generate most part of the renewable energy, a significant part of it being obtained from biomass. In the last 15 years, generation of wind and solar energy has sharply increased at the global level. Experts predicted that by 2040 RES will have a share of $50 \%$ in the world energy consumption [6].

The demand for energy in European countries and the increasing wellbeing and standards of living determined these states to increase production and utilization of renewable energy $[7,8]$. Energy plays a central role in national economic development. It may also have a leverage effect on economic growth. The economic systems of the EU states are directly influenced by the energy policy at the 
EU level. The European energy system should respond to climate change challenges and support the achievement of sustainable growth in the EU member States [9]. The EU countries with higher GDP succeeded in making progress in production and utilization of renewable energies as higher economic development level provides more financial resources and opportunities to invest in new renewable energy technologies also taking into account geographical conditions of these countries [9]. Another possible explanation would be the fact that in the EU developed Member States the transition from fossil fuels to renewable energy sources is encouraged by well-developed national legislative frameworks and strong institutions. The implementation of RES technologies are not regulated by political actions. The subsidies, tax credits, financial assistance and rebates are well-established in favour of renewable technologies in developed market economies. Transition countries having lower GDP per capita and less developed energy markets, have weaker institutions and policy frameworks to support RES as well as less budget resources to provide financial support for RES technologies $[9,10]$.

Economic sustainability might be ensured by allocation of emission allowances and energy efficiency $[10,11]$. The Renewable Energy Directive, known as 2009/28/EC, establishes the EU policy in terms of energy production from RES. According to the mentioned directive a minimum of $20 \%$ RES in the total energy of the EU countries is required by 2020, specific targets being set up for each state. The framework on climate and energy as to 2030 imposes a minimum of $27 \%$ in what concerns the share of RES consumption [12-14].

RES development does not compromise economic growth or employment [12], moreover, it may bring some additional financial advantages [15]. The literature reports that there are business models that depend on the category of resources and various characteristics of industrialized and developing economies [16-18].

Solar power and wind are intermittent resources, but this disadvantage can be eliminated by cross-border and cross-sector cooperation $[19,20]$. The EU has proposed a low-carbon energy system with a growing share of renewable electricity sources [21] and an ambitious goal of $100 \%$ renewable energy [22].

Only eleven states have already achieved the 2020 targets [23]. A comparative research between the countries that might reach the national targets is necessary in this context. For instance, Denmark, Austria, Finland and Sweden are leaders in terms of the Europe 2020 Strategy [24] implementation, while France, Germany, Portugal, Italy, Lithuania, Croatia, Ireland, and Latvia have values greater than the EU average, with respect to environmental and energy performance [25]. Italy, Austria, Portugal, Latvia, and France are top performers in terms of environmental protection [26]. RES as capital influences the GDP, a retraction correction being observed when economic growth generates the growth of renewable energy consumption. The EU candidate countries need to foster the development of renewable energy [27]. For the EU-28, the results indicate that a growth of $1 \%$ in primary production of RES generates an increase of $0.05-0.06 \%$ in GDP per capita [28]. Trajectories towards national targets are also analyzed in [29]. Difficulties of several countries in reaching the targets can be described as follows: The Netherlands and Malta have problems with the levels of GHG emissions [30], while The Netherlands, France, Luxembourg, Ireland, and the United Kingdom encountered difficulties with the share of RES [31].

There is a plethora of studies [17-46] analyzing the relationship between renewable energy consumption and macroeconomic indicators from different perspectives and using different methodologies. A part of these studies constructed a renewable energy sustainability index that was applied for the $15 \mathrm{EU}$ countries that are different according to level of final energy consumption and degree of economic development [21]. Another study analyzed energy per capita for 19 Eurozone countries [25]. A consistent part of researches are focused on the relationship between energy consumption/renewable energy consumption and different macroeconomic variables, like economic growth in Europe (for the EU-28 countries [21], new EU member states [27], 42 developing countries [23], main renewable energy consuming countries in the world [25], 15 former Soviet Union countries [24],), capital and labour (new EU member states [29]), urbanization (residential sector [36]). Lung [31] 
offered own division into the groups of countries according to output and energy consumption basing on the data for both developed and developing countries. Previously, a comparative analysis among the EU-28 member states according to the RES share in gross final consumption was carried out by Cucchiella et al. [10] using different mathematical models. The authors showed that Finland and Sweden achieved the best results concerning gross final energy consumption, while Austria, Denmark, and Latvia reached the 2020 target in the share of energy from renewable sources in the gross final consumption. Moreover, the authors showed that some EU countries will never achieve the 2020 targets (France, Belgium, The Netherlands, Luxembourg, UK).

A special consideration was assigned to the advantages of renewable energy technologies in the case of emerging countries [40,41]. Sadorsky proposed two empirical models to capture the connection between income and renewable energy consumption in some emerging economies. A cointegration relationship was identified and growth in the case of real per capita income had a positive and significant influence on per capita renewable energy consumption. If real income per capita grows by $1 \%$ in the long run, consumption of renewable energy per capita in emerging economies increases by around 3.5\% [42].

There are many studies dealing with forecasts of energy consumption from renewables based on various quantitative methods and on the data of the EU-28 countries [43-50] Considering the European Commission principal objective to extend the share of renewable energy production in electricity, the aim of this research is to explain the renewable energy in electricity based on GDP per capita, seen as a measure of standard of living and income inside the EU, in the period of 2007-2017. Knowing the advantages of RES related to environmental protection and reduction of GHG emissions, this paper checks whether the increase in renewable energy in electricity has a positive effect on the EU countries' economies. This objective is achieved by focusing on two directions of research: the explanation of a share of renewable energy in electricity based on GDP per capita using panel data models and checking Granger causality on stationary panel data, and the study of groups of the EU countries according to their shares of renewable energy in electricity using cluster analysis.

Most of the studies in literature address energy consumption in its correlation to various macroeconomic indicators, less attention being given to the analysis of the renewable energy in the electricity subsector specifically.

This analysis provides useful conclusions on the share of renewable energy in electricity in relation to output per capita, while all previous studies have been connecting this indicator only with economic growth. None of the studies links the share of renewable energy in electricity to per capita GDP. The novelty of this research is also ensured by application of other methods than those used before to study this kind of relationship. In our case, the results based on an overall analysis of the countries using panel data analysis are combined with the results on individual analysis of the countries based on cluster method.

The paper has a standard logical organization. The current section provides details on theoretical background with some references from literature, while the methodology is presented briefly in Section 2. In Section 3, we report the main results with corresponding economic comments. Finally, in the last section, a deeper discussion is presented.

\section{Method and Data}

As we mentioned before, the share of renewable energy in electricity will be analyzed in relation with real GDP per capita for the EU-28 countries. This empirical study employs two methods: panel data models, including the study of causality in panel, and cluster analysis for identifying groups of countries according to share of renewable energy in electricity and their economic development expressed by GDP per capita.

The variables that have been employed in this research refer to the share of renewable energy in electricity (\%), the supply of electricity as gross electricity production in Gigawatt-hour, electricity price for non-household consumption in Purchasing Power Standard (consumption less than $20 \mathrm{MWh}$-band 
IA, comparable prices) and real GDP per capita (expressed in constant 2010 US dollars). The data on these variables were collected for the EU-28 countries for the period of 2007-2017. The data on the share of renewable energy in electricity are taken from the Statista database, while the World Bank provided the data for GDP per capita. The data on electricity supply and electricity prices for non-households are provided from the Eurostat database and the supply of energy plays the role of a control variable in the panel data models. Other theoretical and empirical studies used $\mathrm{CO}_{2}$, GHG emissions or population as their explanatory variables [8,9]. The data on $\mathrm{CO}_{2}$ and GHG emissions are not available for the analyzed period for all the EU Member States. Population is not relevant in this case since GDP per capita is an indicator computed using data on population. Data on electricity price per household consumption are available only since 2017.

In this paper, renewable energy sources (RES) refer to those sources of energy that are flow-limited and naturally replenishing: biomass (biodiesel, wood, solid and wood waste, ethanol, biogas, landfill gas), wind, hydropower, solar source, geothermal sources etc. This indicator shows the proportion of electricity derived from renewable sources in each EU country.

The electricity prices for non-household consumers are computed for end users based on the predefined yearly consumption band. Three levels of taxation are considered in calculation of these prices (prices excluding VAT and the rest of recoverable taxes, prices excluding levies and taxes, prices including all taxes, VAT and levies). Gross electricity production/generation describes the process of producing electrical energy. In this case, electrical energy is obtained by transforming different other existing forms of energy. Luxembourg is the country with the highest values of the GDP per capita in the entire period, these values being considered outliers. The maximum value of this indicator was achieved by Luxembourg in 2015 (77,400 constant 2010 US dollars). Bulgaria is the country with the lowest values of GDP per capita, the minimum being registered in 2007 (10,400 constant 2010 US dollars). Considering the global economic crisis started in 2008 in the US, all the countries, but for Poland, registered lower values of GDP per capita in 2009 as compared to 2008, the effects of the crisis being immediately reflected in the values of output per capita. In Poland, the GDP per capita maintained its value on the 2008 level. Indeed, Poland is considered to be the single EU country not affected by the recent world economic crisis due to its large local market and favourable business environment. Austria has the highest shares of renewable energy in electricity in the EU, the maximum value being achieved in 2017 (72.6\%), being also among the countries with high values of GDP per capita. On the other hand, Malta is the state with the lowest share of renewable energy in electricity, a null value being registered in the period of 2007-2010. Some causes for low performance of Malta would be: small population, planning policies that respond to the ascending demand of accommodation through buildings that require shadowing of rooftops instead of PV installation.

We will build traditional panel data models: fixed-effects model, random-effects model and model based on generalized estimating equation. The last type of model is used to explain the structure of the within-panel correlation. It corresponds to population-averaged (or marginal) models that are described in the panel-data literature.

The fixed-effects model has the following representation:

$$
\mathrm{Y}_{\mathrm{it}}=\alpha+\mathrm{X}^{1}{ }_{\mathrm{it}} \cdot \beta_{1}+\ldots+\mathrm{X}^{\mathrm{k}}{ }_{\mathrm{it}} \cdot \beta_{\mathrm{k}}+\mu_{\mathrm{i}}+\mathrm{v}_{\mathrm{it}}
$$

where $\mathrm{Y}$ is the dependent variable, $\mathrm{X}$ - exogenous variables, $\mathrm{i}$-index for country, $\mathrm{t}$-index for year, $v_{\text {it }}$-idiosyncratic error, $\mu_{\mathrm{i}}$-error for cross-sections

The fixed-effect model uses the following assumptions:

- unobservable individual effects are considered as fixed parameters;

- $\quad$ the exogenous variables are not correlated with idiosyncratic error $v_{i t}$ but correlate with individual fixed effects;

- $\quad$ the idiosyncratic errors $\mathrm{v}_{\mathrm{it}}$ should be independent and identically distributed (iid $\left(0, \sigma^{2}{ }_{\mathrm{v}}\right)$. 
The random-effects model uses the following assumptions:

- unobservable individual effects are considered random variables;

- the exogenous variables do not correlate with idiosyncratic error $\mathrm{v}_{\text {it }}$ or with individual effects;

- $\quad$ the idiosyncratic errors $\mathrm{v}_{\mathrm{it}}$ should be independent and identically distributed (iid $\left(0, \sigma^{2}{ }_{v}\right)$ ) [51].

In the case of one explanatory variable, the model has the representation given below:

$$
Y_{i t}=\alpha+X_{i t} \cdot \beta+\mu_{i}+v_{i t}
$$

The average in time is obtained:

$$
\operatorname{average}\left(Y_{i}\right)=\alpha+\operatorname{average}\left(X_{i}\right) \cdot \beta+\mu_{i}+\operatorname{average}\left(v_{i}\right)
$$

The difference between the two previous equations is made:

$$
\mathrm{Y}_{\mathrm{it}}-\operatorname{average}\left(\mathrm{Y}_{\mathrm{i}}\right)=\left(\mathrm{X}_{\mathrm{it}}-\operatorname{average}\left(\mathrm{X}_{\mathrm{i}}\right)\right) \cdot \beta+\left(\mathrm{v}_{\mathrm{it}}-\operatorname{average}\left(\mathrm{v}_{\mathrm{i}}\right)\right)
$$

This internal transformation is required for determining the fixed-effect estimator. The least squares method is applied in the model (4) and the estimators for $\beta$ with fixed-effects are calculated.

For testing Granger causality in panel data, we should start from the regression:

$$
\mathrm{Y}_{\mathrm{it}}=\alpha_{\mathrm{i}}+\sum \mathrm{Y}_{\mathrm{i}(\mathrm{t}-\mathrm{k})} \cdot \beta_{\mathrm{ik}}+\sum \mathrm{X}_{\mathrm{i}(\mathrm{t}-\mathrm{k})} \gamma_{\mathrm{ik}}+\varepsilon_{\mathrm{it}}
$$

The data series for variables $X$ and $Y$ should be stationary to check Granger causality between them. The coefficients should differ across countries ( $t$-index for time, $i$-index for countries), but are constant in time. The lag order is $\mathrm{K}$ and it should be constant for all the countries in the balanced panel. Granger causality test implies the identification of significant effects of previous values of $X$ on the actual values of $Y$. The null hypothesis is stated as:

$\mathrm{H} 0: \gamma_{\mathrm{i} 1}=\gamma_{\mathrm{i} 2}=\ldots=\gamma_{\mathrm{iK}}=0, \mathrm{i}=1,2, \ldots, \mathrm{N}$; where $\mathrm{N}$ is the number of cross-sections (countries)

Firstly, the data stationarity was checked using a Levin-Lin-Chu (LLC) test and further estimations are made on stationary panel data. The null hypothesis for LLC test states that the panels include unit root, while the alternative hypothesis, rejected when the p-value is higher than $0.05 / 0.1$ (at the $5 \%$ and $\mathrm{s}$ of significance), confirms that panels are stationary. We chose the estimates with robust standard errors in order to avoid additional checks for errors' heteroskedasticity loose the critical value or when the p-value is higher than $0.05 / 0.1$, at the $5 \% / 10 \%$ levels of significance.

Cluster analysis is used to identify groups of countries by GDP per capita and share of renewable energy in electricity. In this case, we used a non-hierarchical classification with K-mean clusters. The k-average method starts from $\mathrm{k}$ values that are used to build groups. The distance to cluster is computed using the Ward method that implies more steps:

- $\quad$ for the analyzed variable, the sum of the squares of the deviations of each country in the cluster from average is computed, in order to minimize the square of the error squares, for example, to minimize the loss of information;

- $\quad$ for every step of the algorithm, any pair of countries that could be joined in a particular cluster is analyzed and we unify the pair that with the minimum loss of information.

There is not any strong statistical criterion for determining the number of clusters that should be considered at a certain probability. The optimal number of clusters is fixed considering some hints:

- $\quad$ theoretical motivation;

- previous use of non-hierarchical methods; 
- $\quad$ results of variance analysis;

- $\quad$ figures representing the countries.

The k-means method supposes the following steps:

(1) k initial classes are considered (each country is placed in one class);

(2) A country is moved in that cluster for which the average or centroid is the closest;

(3) The average is computed again for the two clusters in which that country was at different moments;

(4) The previous two steps are repeated until changes are made.

We have chosen a panel data approach since we are describing here an overall image of the relationship between RES in electricity and GDP per capita in the EU countries. Moreover, cluster analysis was applied in order to have a deeper understanding on the tendencies in each country.

\section{Empirical Results}

A Nalimov test was applied to check for outliers in the data series. For Luxembourg, all the values of GDP per capita were outliers since the test statistics (for example, 18.93 for 2007 and 27.99 for 2017) were higher than the critical value of 1.95 at the $5 \%$ level of significance. Since Luxembourg is considered an outlier because of the high level of GDP per capita, we eliminated this country from the panel data models. Two main goals were followed by the empirical analysis:

- $\quad$ A study of the relationship between share of renewable energy in electricity and GDP per capita based on panel data models and Granger causality;

- An analysis of the groups of countries in the EU-28 according to share of renewable energy in electricity and GDP per capita.

All the computations were made using the STATA software. Firstly, we tested whether the data in panel are stationary. Levin-Lin-Chu test indicated that the data series for both variables are stationary at the $10 \%$ level of significance. According to LLC test, the data series are stationary in panel for all the variables at the $10 \%$ level of significance: GDP per capita (adjusted $t=4.23, p$-value $=0.000$ ), supply of electricity (adjusted $t=1.98, p$-value $=0.09$ ), electricity prices for non-household consumers (adjusted $\mathrm{t}=2.23, p$-value $=0.04)$.

More panel data models were built to explain the share of renewable energy in electricity in the EU-28 countries in the period of 2007-2017: generalized linear models, random-effects and fixed-effects models. According to Pesaran's CD test, the cross-sectional units are independent at the 5\% level of significance. All the models indicated that growth of GDP per capita by one unit determined, on average, an increase in the share of renewable energy in electricity by almost 0.001 percentage points. In other words, an increase in GDP per capita by 1000 units are necessary to extend the share of renewable energy in electricity by only one percentage points (see Table 1).

Table 1. Panel data models to explain the share of renewable energy in electricity in the EU member states (2007-2017).

\begin{tabular}{|c|c|c|c|c|c|c|c|c|c|}
\hline \multirow[t]{2}{*}{ Variable } & \multicolumn{3}{|c|}{ Generalized Estimating Equation } & \multicolumn{3}{|c|}{ Random-Effects GLS Equation } & \multicolumn{3}{|c|}{ Fixed-Effects (within) Regression } \\
\hline & Coefficient & $\begin{array}{l}\text { Chi-square } \\
\text { stat. }\end{array}$ & $p$-value & Coefficient & $\begin{array}{l}\text { Chi-square } \\
\text { stat. }\end{array}$ & $p$-value & Coefficient & $\begin{array}{l}\text { Chi-square } \\
\text { stat. }\end{array}$ & $p$-value \\
\hline Constant & -1.52 & -0.32 & 0.70 & -0.15882 & -0.04 & 0.969 & -1.92 & -1.44 & 0.17 \\
\hline Supply of electricity & 0.89 & 7.99 & 0.000 & 0.92 & 9.03 & 0.000 & 0.89 & 9.20 & 0.000 \\
\hline $\begin{array}{l}\text { Pesaran's test for } \\
\text { cross-section } \\
\text { independence }\end{array}$ & & 12.27 & 0.14 & & 13.56 & 0.27 & & 12.57 & 0.15 \\
\hline
\end{tabular}

Source: own results. 
This result indicates that other factors should contribute to the growing share of renewable energy in electricity, maintaining the concern for growing GDP per capita. This result supports the hypothesis stated in the introduction: more developed countries tend to use more RES as compared to less developed countries. However, still more efforts to grow GDP per capita are required in the EU to have an acceptable increase in RES. As expected, the control variable (electricity supply) has a positive and significant impact on the dependent variable. The increase in electricity production overall brought to a higher share of renewable energy in electricity. In other words, renewable energy is more used in electricity since electricity production overall has increased to correspond to the growing needs in energy. We applied a Hausmann test to select the best model between fixed-effects model and random-effects model. The statistics of the test is $45.78(p$-value $=0.000)$ which indicates that fixed-effects model explains better than random-effects model the share of renewable energy in electricity in the EU countries at the $5 \%$ level of significance. The values of R-square also indicate fixed-effects model as better (R-square in this case is 0.803 , while for random-effects model R-square is 0.71 and for generalized estimating equation $\mathrm{R}$-square is 0.76 ). This can be explained by the fact that the increase in electricity prices shapes the of renewables in the increase of the share of renewables in electricity production. However, a significant causality in Granger approach was not identified between GDP per capita and share of renewable energy in electricity at $5 \%$ level of significance (see Table 2 ).

Table 2. Granger causality test applied on panel data to explain the connection between the share of renewable energy in electricity and GDP per capita in the EU-28 (2007-2017).

\begin{tabular}{ccc}
\hline Hypothesis & Chi-Square & Prob. \\
\hline $\begin{array}{c}\text { Share of renewable energy in electricity does } \\
\text { Granger cause GDP per capita }\end{array}$ & 2.307 & 0.3155 \\
\hline $\begin{array}{c}\text { GDP per capita does Granger cause share of } \\
\text { renewable energy in electricity }\end{array}$ & 3.039 & 0.218 \\
\hline
\end{tabular}

Source: own results.

Some clusters were formed for 2007 and 2017 to reflect the countries in what concerns share of renewable energy in electricity and according to the share of renewable energy in electricity and GDP per capita.

According to the share of renewable energy in electricity, Table 3 describes the two clusters obtained for 2007:

- countries with high shares of renewable energy in electricity (more than 30\%): Austria (64\%), Sweden (53.2\%), Latvia (38.6\%), Croatia (34\%) and Portugal (32.3\%) (these percentages are provided to have an idea about the difference between the countries in the same group);

- countries having lower shares of renewable energy in electricity (less than $30 \%$ ) for the rest of the EU-28 countries.

When both the share of renewable energy in electricity and GDP per capita are considered, Table 3 presents a number of three clusters in 2007:

- countries having high GDP per capita and relative high shares of renewable energy in electricity;

- Luxemburg that is considered an outlier because of the high values of GDP per capita;

- $\quad$ some countries with lower GDP per capita.

Two clusters were selected for the share of renewable energy in electricity and three clusters for the approach based on both variables. We selected these numbers since significant differences between the groups were allowed. We have thee clusters for the second approach, since Luxembourg is an outlier that is different from all other countries. 
Table 3. Groups of countries in the EU-28 according to the share of renewable energy in electricity and GDP per capita in 2007.

\begin{tabular}{|c|c|c|c|c|}
\hline \multicolumn{2}{|c|}{$\begin{array}{l}\text { Clusters according to the Share of } \\
\text { Renewable Energy in Electricity in } 2007\end{array}$} & \multicolumn{3}{|c|}{$\begin{array}{l}\text { Clusters according to the Share of Renewable Energy in } \\
\text { Electricity and GDP per Capita in } 2007\end{array}$} \\
\hline Cluster 1 & Cluster 2 & Cluster 1 & Cluster 2 & Cluster 3 \\
\hline $\begin{array}{c}\text { Austria, Portugal, } \\
\text { Croatia, Latvia, } \\
\text { Sweden }\end{array}$ & $\begin{array}{c}\text { Bulgaria, Belgium, } \\
\text { Cyprus, Estonia, } \\
\text { Denmark, Finland, } \\
\text { Greece, Hungary, } \\
\text { France, Germany, } \\
\text { Ireland, Italy, } \\
\text { Poland, Slovenia, } \\
\text { Lithuania, Malta, } \\
\text { Spain, Netherlands, } \\
\text { Romania, Slovakia, } \\
\text { the UK, } \\
\text { Luxembourg }\end{array}$ & $\begin{array}{l}\text { Austria, Belgium, } \\
\text { Cyprus, Denmark, } \\
\text { Finland, France, } \\
\text { Germany, Ireland, } \\
\text { Italy, Netherlands, } \\
\text { Spain, UK, Sweden }\end{array}$ & Luxembourg & $\begin{array}{c}\text { Croatia, Bulgaria, } \\
\text { Czech Republic, } \\
\text { Estonia, Greece, } \\
\text { Hungary, Latvia, } \\
\text { Lithuania, Malta, } \\
\text { Poland, Portugal, } \\
\text { Slovakia, Slovenia, } \\
\text { Romania }\end{array}$ \\
\hline
\end{tabular}

Source: own results.

As we can observe from Figure 1, Austria is the country with the highest share of renewable energy in electricity in 2007, but also in 2017, being followed by Sweden. Malta is the single country with null share of renewable energy in electricity in 2007, being followed by Cyprus with a share of $0.1 \%$ in 2007 . However, after 10 years, all the countries improved their share of renewable energy in electricity.

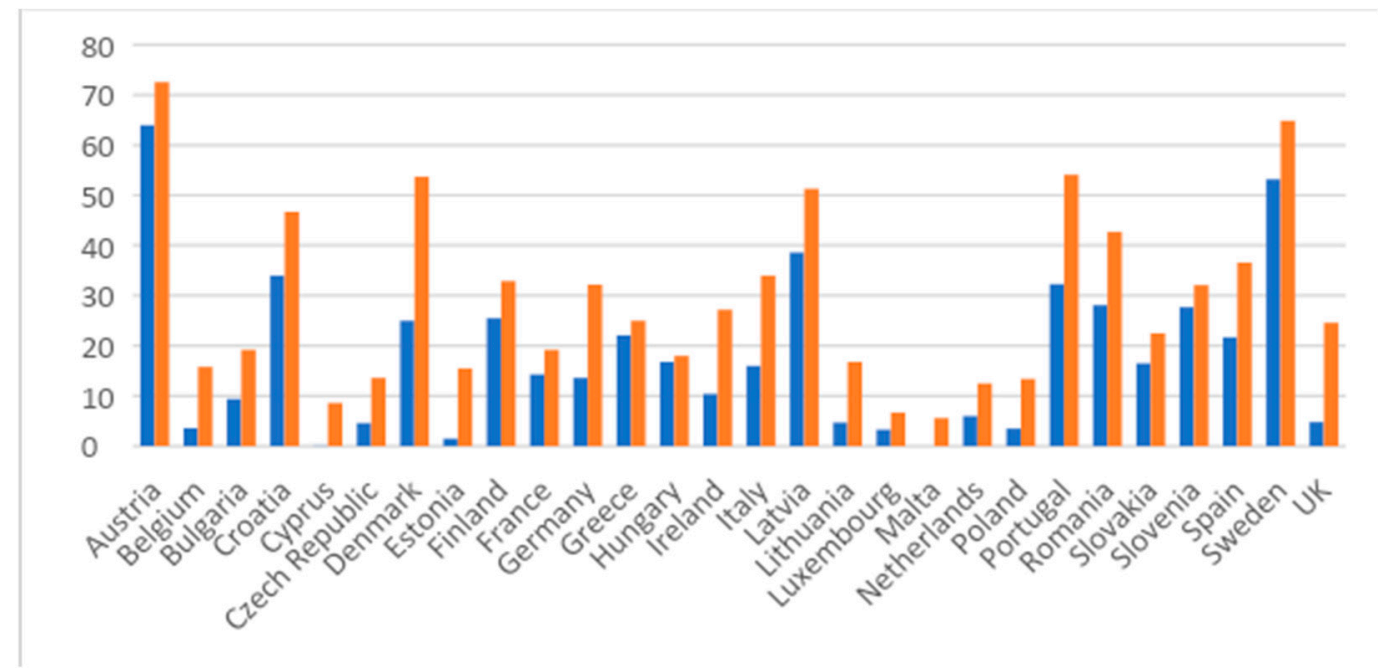

Figure 1. Share of renewable energy in electricity in 2007 and 2017 in the EU-28 countries (blue-2007, orange-2017). Source: own results.

Austria was the leader in 2007 in terms of share of renewable energy in electricity, this country being successful in what concern sources like biomass from wood, hydropower (a share of more than $96 \%$ in renewable energy in electricity) and use of thermal solar energy [47,51].

$80 \%$ percent of electricity production in Sweden is based on hydroelectric and nuclear power, fact that explains the low emission rate in this country. It has three nuclear plants and eight nuclear reactors. Wind power ensures around 11 percent of electricity, power plants and hear ensure nine percent of electricity in Sweden [52].

In Latvia, hydropower plants have the highest proportion in electricity production (more than $98 \%$ ). Gas also has a significant contribution to internal supply of electricity, wind and biomass contributing to the mix mostly in recent years [53]. 
In Croatia, renewable energy rapidly expanded. Wind and solar PV energy the most rapidly expanded, while hydropower and solar thermal developed slower [54].

In Portugal, the main sources of renewable energy are represented by: hydropower, wind power, solar power, geothermal and wave power, biogas [55].

According to share of renewable energy in electricity, Table 4 shows that there are two clusters in 2017:

- a group of countries with high shares of renewable energy in electricity (more than $40 \%$ which is an increase compared to 2007): Austria (72.6\%), Sweden (64.9\%), Latvia (51.3\%), Croatia (46.7\%), Denmark (53.7\%), Romania (42.7\%) and Portugal (54.1\%);

- a group of countries with lower shares of renewable energy in electricity (less than $40 \%$ ) in the case of the other EU-28 countries.

According to share of renewable energy in electricity and GDP per capita, Table 4 shows that there are three clusters in 2017:

- $\quad$ a group of countries with high GDP per capita and relative high shares of renewable energy in electricity;

- $\quad$ Luxemburg that is considered an outlier in terms of GDP per capita;

- $\quad$ a group of countries with lower GDP per capita.

Table 4. Groups of EU countries according to share of renewable energy in electricity and GDP per capita in 2017.

\begin{tabular}{|c|c|c|c|c|}
\hline \multicolumn{2}{|c|}{$\begin{array}{l}\text { Clusters Based on Share of Renewable } \\
\text { Energy in Electricity in } 2017\end{array}$} & \multicolumn{3}{|c|}{$\begin{array}{l}\text { Clusters Based on Share of Renewable Energy in } \\
\text { Electricity and GDP per Capita in } 2017\end{array}$} \\
\hline Cluster 1 & Cluster 2 & Cluster 1 & Cluster 2 & Cluster 3 \\
\hline $\begin{array}{c}\text { Denmark, Austria, } \\
\text { Croatia, Portugal, } \\
\text { Latvia, Romania, } \\
\text { Sweden }\end{array}$ & $\begin{array}{l}\text { Belgium, Bulgaria, } \\
\text { Hungary, Italy, Cyprus, } \\
\text { Ireland, Netherlands, } \\
\text { Greece, Lithuania, } \\
\text { Estonia, Ireland, } \\
\text { Germany, Finland, } \\
\text { France, Luxembourg, } \\
\text { Slovakia, Poland, } \\
\text { Slovenia, Malta, UK }\end{array}$ & $\begin{array}{l}\text { Austria, France, } \\
\text { Belgium, Germany, } \\
\text { Netherlands, } \\
\text { Sweden }\end{array}$ & $\begin{array}{c}\text { UK, } \\
\text { Luxembourg, } \\
\text { Denmark, } \\
\text { Finland }\end{array}$ & $\begin{array}{c}\text { Croatia, Malta, } \\
\text { Bulgaria, Slovenia, } \\
\text { Czech Republic, } \\
\text { Italy, Estonia, } \\
\text { Romania, Portugal, } \\
\text { Slovakia, Greece, } \\
\text { Hungary, Cyprus, } \\
\text { Latvia, Lithuania, } \\
\text { Spain, Poland }\end{array}$ \\
\hline
\end{tabular}

Source: own results.

In 2017, Denmark and Romania were the countries that achieved also high shares of renewable energy in electricity together with the states that acted like leaders in 2007. Denmark counts among world leading countries in wind energy production. Other sources are less used: wood, waste, solar power, straw, biogas. However, Denmark is among the countries with the less utilization of hydropower [56]. In Romania, biomass and biogas is the most considerable source of energy used in electricity, being followed by less used ones: wind, solar, hydro sources [57].

\section{Discussion}

This paper has aimed to assess the impact of GDP per capita on penetration of RES and its effects in improving real GDP per capita as well. The objective character of the achieved results is ensured by utilization of historical data and applied statistical methods. This work also highlights the importance of producing more energy from RES for the countries to improve their economic growth and standards of living as the increase in the share of renewables provides for increase in standards of living because RES are based on new technologies, create new jobs, boost external benefits for the society, including pollution reduction and 
The EU countries were distributed into two large groups basing on the shares of renewable energy in electricity. This research also confirms the necessity to implement important policy measures to promote more active use of RES, taking into account the RES potential available in a country.

One of the main goal in this research has been studying the relationship between the share of renewable energy in electricity and real GDP per capita. Many of the previous research focused on correlation between economic development and energy production or/and consumption. We have chosen GDP per capita since it reflects the achieved level of economic development in the long run and population well-being is a final goal followed by all citizens, and also by government [58-62].

One of our important results is revealing the lack of causality between the two variables (the share of renewable energy in electricity and real GDP per capita). This means that production of energy from RES is not so high as to ensure on long-run economic welfare. Other important macroeconomic variables need to be taken into account when assessing the impact of RES on economic growth.

On the other hand, developed countries of the EU do not necessarily have high share of renewable energy in electricity and this is mainly linked to geographical conditions and physical renewable energy potential. There are numerous examples in this regard. Rich countries like Belgium, France, Germany, Ireland, Italy, The Netherlands, Luxembourg, and the UK registered shares of renewable energy in electricity lower than the EU average in 2007 [60]. Except for Germany, these countries also registered lower values than the 2017 European average for the same indicator.

The proposed panel data models suggested that GDP per capita influences the share of renewables in electricity positively and statistically significantly although this impact is very small. A consistent increase in the GDP per capita is necessary to extend the share of renewable energy in electricity [42]. Economic development level of a country has its impact on RES as it allows generating more financial resources to promote renewables as well advanced economies have better developed mature energy markets, better institutional indicators, industrial know-hows, community policies, technological development level, and citizens' openness to business having also positive impact on RES penetration [12,15].

One of the EU strategies is to reduce the final energy consumption and this objective could be achieved following two patterns: improvement of energy efficiency and growth of the share of renewable energy in final energy consumption and, as an effect of this by growing the share of renewable energy in electricity. If this goal is achieved, many benefits are obtained: sustainable development, reduction of global warming, environment protection, reduction of the dependence on energy imports [61].

The enhancement of renewable energy consumption has been observed since 2010 in the EU Member States, as an effect of EU Directive given in the year 2009 [62]. Even if most of the EU member states are on an upward trend, the achievement of the 2020 target it not secure, knowing that investments in renewable energy production have slowed down since 2015. Spain and Belgium focused more on the consumption of electricity from RES, the rest of the consumption being based on other types of fuels. Poland made important efforts to increase renewable energy consumption, but for achieving the 2020 target, has to boost production from RES. Austria, Denmark, Finland, and Sweden are countries where RES plays an important role in the energy mix [63]. In these countries, the lack of fossil fuel resources and the climatic conditions forced society and industry to reduce at minimum the energy consumption.

Even if significant investments were made in the UK for increasing the production capacity of RES, especially for solar panels, this country is far from achieving the EU target. The uncertain context of Brexit creates more barriers. Germany made big progress in the consumption of fossil and nuclear fuels, while France and Italy have serious problems in meeting the targets for 2020 [64-69]. Netherlands also encountered difficulties because its final energy consumption is based on a natural gas network that is quite cheap; government subsidies for the RES promotion are not attractive, being lower than in Scandinavian countries. 
Portugal has invested heavily in RES, but high costs did not allow it to maintain a high increase from one year to another. Czech Republic, Romania, and Hungary have a rich network of RES, but the efforts to meet EU target intensified after these countries joined the EU [70,71].

In some EU countries, the target value for 2020 in the case of share of renewable sources in gross final consumption was exceeded: Hungary and Estonia since 2011, Sweden and Bulgaria since 2012, Czech Republic since 2013, and Romania, Lithuania, Italy, and Finland since 2014. By increasing this share, the EU countries will be able to significantly reduce greenhouse gas emissions and improve the environment quality.

This analysis is limited by the fact that only a few variables were considered in the panel data models because of their availability for that specific period and for the EU countries. Moreover, a larger period would have been required for a deeper analysis, however, the data on all the variables in the models are available only since 2007. In the future other important variables will be included in the model and countries will be grouped into clusters according to their geographical conditions and physical RES potential available.

\section{Conclusions}

The panel data models indicated a positive, but very low impact of GDP per capita on the share of RES in electricity in the period of 2007-2017 in the case of the EU countries. However, causality between the two variables was not identified.

The EU member states were grouped by means of cluster analysis, however, future research would be necessary to get more robust results and develop specific policy recommendations. The extension of this model is required by including other important variables such as RES potential available in the countries based on geographical conditions and other important factors which were not addressed in this study.

Economic development level of countries is supposed to have significant impact on the exploration of RES potential taking into account geographical conditions of the countries in question. Higher economic development level first of all allows raising more funds for renewable energy support. As the old EU member states have also more developed energy markets, stronger institutions and legal frameworks, lower corruption perception levels, these issues need to be further explored.

Some other aspects need deeper analysis as well, namely, the political, social, economic, environmental, and technological determinants behind weaknesses and strengths of renewable resources. It is also important to assess the effects on RES expansion of the following specific factors: policies promoting RES, investments in the field of research and development, internal energy production, industrial know-hows, community policies, energy dependency, technological development level, and citizens' openness to business, institutional indicators such as corruption perception, regulation quality etc.

RES as such is supposed to have a positive impact on economic growth as it provides new jobs, technological innovations and also promotes GDP growth. Therefore, it is important to analyse the impact of RES deployment level on economic, social and environmental indicators of the countries, however, additional variables need to be integrated into the model as also having impact on GDP per capita growth rate.

Author Contributions: Conceptualization, M.S. and D.S.; Methodology, M.S., D.S., Y.B., E.K. and S.G.; Formal Analysis, M.S., Y.B. and E.K.; Investigation, Y.B., S.G. and D.S.; Resources, Y.B., E.K. and S.G.; Data Curation, M.S.; Writing-Original Draft Preparation, M.S., D.S. and S.G.; Writing-Review \& Editing, M.S. and D.S.; Visualization, M.S.; Supervision, D.S., Y.B. and E.K.; Funding Acquisition, Y.B., E.K. and S.G.

Funding: This research received no external funding.

Conflicts of Interest: The authors declare no conflict of interest. 


\section{References}

1. Wu, Q.; Zhou, J.; Liu, S.; Yang, X.; Ren, H. Multi-objective Optimization of Integrated Renewable Energy System Considering Economics and $\mathrm{CO}_{2}$ Emissions. Energy Procedia 2016, 104, 15-20. [CrossRef]

2. Dudin, M.N.; Frolova, E.E.; Protopopova, O.V.; Andrey Alievich Mamedov, A.A.; Odintsov, S.V. Study of innovative technologies in the energy industry: Nontraditional and renewable energy sources. Entrep. Sustain. Issues 2019, 6, 1704-1713. [CrossRef]

3. Lavrinenko, O.; Ignatjeva, S.; Ohotina, A.; Rybalkin, O.; Lazdans, D. The Role of Green Economy in Sustainable Development (Case Study: The EU States). Entrep. Sustain. Issues 2019, 6, 1013-1026. [CrossRef]

4. Pfenninger, S.; Keirstead, J. Renewables, nuclear, or fossil fuels? Scenarios for Great Britain's power system considering costs, emissions and energy security. Appl. Energy. 2015, 152, 83-93. [CrossRef]

5. Šahović, N.; da Silva, P.P. Community Renewable Energy-Research Perspectives. Energy Procedia. 2016, 106, 46-58. [CrossRef]

6. Sari, A.; Akkaya, M. Contribution of renewable energy potential to sustainable employment. Procedia Soc. Behav. Sci. 2016, 229, 316-325. [CrossRef]

7. European Parliament. Renewable Energy Sources. 2016. Available online: http://www.europarl.europa.eu/ ftu/pdf/lv/FTU_5.7.4.pdf (accessed on 3 December 2018).

8. Cherchyk, L.; Shershun, M.; Khumarova, N.; Mykytyn, T.; Cherchyk, A. Assessment of forest enterprises' performance: Integrating economic security and ecological impact. Entrep. Sustain. Issues 2019, 6, 1784-1797. [CrossRef]

9. Cucchiella, F.; Adamo, I.; Gastaldi, M. Biomethane: A renewable resource as vehicle fuel. Resources. 2017, 6, 58. [CrossRef]

10. Cucchiella, F.; D'Adamo, I.; Gastaldi, M.; Miliacca, M. Efficiency and allocation of emission allowances and energy consumption over more sustainable European economies. J. Clean. Prod. 2018, 182, 805-817. [CrossRef]

11. Tvaronavičienè, M.; Nesterova, K.; Kováčik, V. Energy security and long-term energy efficiency: Case of selected counties. J. Secur. Sustain. Issues 2017, 7, 349-357. [CrossRef]

12. Blazejczak, J.; Braun, F.G.; Edler, D.; Schill, W.-P. Economic effects of renewable energy expansion: A model-based analysis for germany. Renew. Sustain. Energy Rev. 2014, 40, 1070-1080. [CrossRef]

13. Frankfurt School UNEP Centre; Bloomberg New Energy Finance (BNEF). Global Trends in Renewable Energy Investment. Frankfurt School-UNEP Centre. 2016. Available online: http://fs-unep-centre.org/sites/default/ files/attachments/press_release_gtr_2016_in_english.pdf (accessed on 27 October 2017).

14. IEA. Energy and Climate Change, World Energy Outlook Special Report. Available online: https://www.iea. org/publications/freepublications/publication/WEO2015SpecialReportonEnergyandClimateChange.pdf (accessed on 7 November 2017).

15. Ruggiero, S.; Lehkonen, H. Renewable energy growth and the financial performance of electric utilities: A panel data study. J. Clean. Product. 2017, 142, 3676-3688. [CrossRef]

16. Engelken, M.; Römer, B.; Drescher, M.; Welpe, I.M.; Picot, A. Comparing drivers, barriers, and opportunities of business models for renewable energies: A review. Renew. Sustain. Energy Rev. 2016, 60, 795-809. [CrossRef]

17. Thellufsen, J.Z.; Lund, H. Cross-border versus cross-sector interconnectivity in renewable energy systems. Energy 2017, 124, 492-501. [CrossRef]

18. Eddelani, O.; El Idrissi, N.E.; Monni, S. Territorialized forms of production in Morocco: Provisional assessment for an own model in gestation. Insights Reg. Dev. 2019, 1, 6-18. [CrossRef]

19. Collins, S.; Deane, J.P.; Ó Gallachóir, B. Adding value to EU energy policy analysis using a multi-model approach with an EU-28 electricity dispatch model. Energy 2017, 130, 433-447. [CrossRef]

20. Masood, O.; Tvaronavičienè, M.; Javaria, K. Impact of oil prices on stock return: Evidence from G7 countries. Insights Reg. Dev. 2019, 1, 129-137. [CrossRef]

21. European Commission. A Policy Framework for Climate and Energy in the Period from 2020 to 2030; European Commission: Juba, South Sudan, 2014; Eurostat. Statistics Database. Available online: http://ec.Europa.Eu/ eurostat/data/database (accessed on 15 May 2017).

22. Fura, B.; Wojnar, J.; Kasprzyk, B. Ranking and classification of eu countries regarding their levels of implementation of the europe 2020 strategy. J. Clean. Prod. 2017, 165, 968-979. [CrossRef] 
23. Cucchiella, F.; D'Adamo, I.; Gastaldi, M.; Koh, S.C.L.; Rosa, P. A comparison of environmental and energetic performance of european countries: A sustainability index. Renew. Sustain. Energy Rev. 2017, 78, 401-413. [CrossRef]

24. García-Álvarez, M.T.; Moreno, B.; Soares, I. Analyzing the environmental and resource pressures from european energy activity: A comparative study of EU member states. Energy 2016, 115, 1375-1384. [CrossRef]

25. Armeanu, D.; Vintilă, G.; Gherghina, Ş. Does renewable energy drive sustainable economic growth? Multivariate panel data evidence for EU-28 countries. Energies 2017, 10, 381. [CrossRef]

26. Bilan, Y.; Streimikiene, D.; Vasylieva, T.; Lyulyov, O.; Pimonenko, T.; Pavlyk, A. Linking between Renewable Energy, $\mathrm{CO}_{2}$ Emissions, and Economic Growth: Challenges for Candidates and Potential Candidates for the EU Membership. Sustainability 2019, 11, 1528. [CrossRef]

27. Štreimikienè, D.; Balezentis, T. Kaya identity for analysis of the main drivers of ghg emissions and feasibility to implement eu "20-20-20" targets in the Baltic states. Renew. Sustain. Energy Rev. 2016, 58, 1108-1113. [CrossRef]

28. Liobikienè, G.; Butkus, M. The European union possibilities to achieve targets of Europe 2020 and paris agreement climate policy. Renew. Energy 2017, 106, 298-309. [CrossRef]

29. D'Adamo, I.; Rosa, P. Current state of renewable energies performances in the European union: A new reference framework. Energy Convers. Manag. 2016, 121, 84-92. [CrossRef]

30. Capros, P.; Paroussos, L.; Fragkos, P.; Tsani, S.; Boitier, B.; Wagner, F.; Busch, S.; Resch, G.; Blesl, M.; Bollen, J. Description of models and scenarios used to assess European decarbonisation pathways. Energy Strategy Rev. 2014, 2, 220-230. [CrossRef]

31. Lund, H. Renewable energy strategies for sustainable development. Energy 2007, 32, 912-919. [CrossRef]

32. Resch, G.; Gephart, M.; Steinhilber, S.; Klessmann, C.; del Rio, P.; Ragwitz, M. Coordination or harmonisation? Feasible pathways for a European res strategy beyond 2020. Energy Environ. 2013, 24, 147-170. [CrossRef]

33. Klessmann, C.; Rathmann, M.; de Jager, D.; Gazzo, A.; Resch, G.; Busch, S.; Ragwitz, M. Policy options for reducing the costs of reaching the European renewables target. Renew. Energy 2013, 57, 390-403. [CrossRef]

34. Markaki, M.; Belegri-Roboli, A.; Sarafidis, $\Upsilon$.; Mirasgedis, S. The carbon footprint of Greek households (1995-2012). Energy Policy 2017, 100, 206-215. [CrossRef]

35. Eurostat. Energy from Renewable Sources (Summary-Results-Shares-2014). Available online: http://ec. Europa.Eu/eurostat/web/energy/data/shares (accessed on 5 February 2016).

36. Rezitis, A.N.; Ahammad, S.M. The relationship between energy consumption and economic growth in South and Southeast Asian countries: A panel vector autoregression approach and causality analysis. Int. J. Energy Econ. Policy 2015, 5, 704-715. [CrossRef]

37. Fumon, N.; Biswas, M.A.R. Regression analysis for prediction of residential energy consumption. Renew. Sustain. Energy Rev. 2015, 47, 332-343. [CrossRef]

38. Salim, R.A.; Shafiei, S. Urbanization and renewable and non-renewable energy consumption in OECD countries: An empirical analysis. Econ. Model. 2014, 38, 581-591. [CrossRef]

39. Anwar, A.; Arshed, N.; Kousar, N. Renewable Energy Consumption and Economic Growth in Member of OIC Countries. Eur. Online J. Nat. Soc. Sci. 2017, 6, 111-129. [CrossRef]

40. Liu, Y. Exploring the relationship between urbanization and energy consumption in China using ARDL (autoregressive distributed lag) and FDM (factor decomposition model). Energy 2009, 34, 1846-1854. [CrossRef]

41. Tzeng, G.H.; Shiau, T.A.; Lin, C.Y. Application of multicriteria decision making to the evaluation of new energy system development in Taiwan. Energy 1992, 17, 983-992. [CrossRef]

42. Sadorsky, P. Renewable energy consumption and income in emerging economies. Energy policy 2009, 37, 4021-4028. [CrossRef]

43. Pappas, S.S.; Ekonomou, L.; Karamousantas, D.C.; Chatzarakis, G.; Katsikas, S.; Liatsis, P. Electricity demand loads modeling using AutoRegressive Moving Average (ARMA) models. Energy 2008, 33, 1353-1360. [CrossRef]

44. Ozturk, S.; Ozturk, F. Forecasting Energy Consumption of Turkey by Arima Model. J. Asian Sci. Res. 2018, 8, 52-60. [CrossRef]

45. Barak, S.; Sadegh, S. Forecasting energy consumption using ensemble ARIMA-ANFIS hybrid algorithm. Electr. Power Energy Syst. 2016, 82, 92-104. [CrossRef] 
46. Yuan, C.; Liu, S.; Fang, Z. Comparison of China's primary energy consumption forecasting by using ARIMA (the autoregressive integrated moving average) model and GM(1,1) model. Energy 2016, 100, 384-390. [CrossRef]

47. Tsai, S.B.; Xue, Y.; Zang, J.; Chen, Q.; Liu, Y.; Zhou, J.; Dong, W. Models for forecasting growth trends in renewable energy. Renew. Sustain. Energy Rev. 2017, 77, 1169-1178. [CrossRef]

48. Tvaronavičienè, M.; Prakapienė, D.; Garškaitè-Milvydienė, K.; Prakapas, R.; Nawrot, Ł. Energy Efficiency in the Long-Run in the Selected European Countries. Econ. Sociol. 2018, 11, 245-254. [CrossRef] [PubMed]

49. Shindina, T.; Streimikis, J.; Sukhareva, Y.; Nawrot, Ł. Social and Economic Properties of the Energy Markets. Econ. Sociol. 2018, 11, 334-344. [CrossRef]

50. Rabe, M.; Streimikiene, D.; Bilan, Y. The Concept of Risk and Possibilities of Application of Mathematical Methods in Supporting Decision Making for Sustainable Energy Development. Sustainability 2019, 11, 1018. [CrossRef]

51. Würzburg, K.; Labandeira, X.; Linares, P. Renewable generation and electricity prices: Taking stock and new evidence for Germany and Austria. Energy Econ. 2013, 40, 159-171. [CrossRef]

52. Rubins, M.; Pilvere, I. Development of renewable energy policy in Latvia. In Proceedings of the 2017 International Conference "ECONOMIC SCIENCE FOR RURAL DEVELOPMENT", Jelgava, Latvia, 27-28 April 2017.

53. Blecich, P.; Petrić, M.; Franković, B. Renewable energy in Croatia: A review of present state and future development. In Proceedings of the 11th ISES Eurosun Conference, Palma, Spain, 11-14 October 2016.

54. Proença, S.; Aubyn, M.S. Hybrid modeling to support energy-climate policy: Effects of feed-in tariffs to promote renewable energy in Portugal. Energy Econ. 2013, 38, 176-185. [CrossRef]

55. Lund, H.; Mathiesen, B.V. Energy system analysis of $100 \%$ renewable energy systems-The case of Denmark in years 2030 and 2050. Energy 2009, 34, 524-531. [CrossRef]

56. Chirila, N. Renewable Energy in Romania; Flanders Investment \& Trade: Brussels, Belgium, 2013; pp. 1-56.

57. Streimikiene, D.; Simionescu, M.; Bilan, Y. The Impact of Biodiesel Consumption by Transport on Economic Growth in the European Union. Eng. Econ. 2019, 30, 50-58. [CrossRef]

58. ŠtreimikienėD Kasperowicz, R. Economic growth and energy consumption: Comparative analysis of V4 and the "old" EU countries. J. Inter. Stud. 2016, 9, 181-194. [CrossRef]

59. Stavytskyy, A.; Kharlamova, G.; Giedraitis, V.; Šumskis, V. Estimating the interrelation between energy security and macroeconomic factors in European countries. J. Inter. Stud. 2018, 11, 217-238. [CrossRef] [PubMed]

60. Simionescu, M.; Albu, L.L.; Raileanu Szeles, M.; Bilan, Y. The impact of biofuels utilisation in transport on the sustainable development in the European Union. Technol. Econ. Develop. Econ. 2017, 23, 667-686. [CrossRef]

61. Soava, G.; Mehedintu, A.; Sterpu, M.; Raduteanu, M. Impact of renewable energy consumption on economic growth: Evidence from European Union countries. Technol. Econ. Develop. Econ. 2018, 24, 914-932. [CrossRef]

62. Zhao, H.; Guo, S. External Benefit Evaluation of Renewable Energy Power in China for Sustainability. Sustainability 2015, 7, 4783-4805. [CrossRef]

63. Ntanos, S.; Skordoulis, M.; Kyriakopoulos, G.; Arabatzis, G.; Chalikias, M.; Galatsidas, S.; Batzios, A.; Katsarou, A. Renewable Energy and Economic Growth: Evidence from European Countries. Sustainability 2018, 10, 2626. [CrossRef]

64. Temiz Dinç, D.; Akdoğan, E.C. Renewable Energy Production, Energy Consumption and Sustainable Economic Growth in Turkey: A VECM Approach. Sustainability 2019, 11, 1273. [CrossRef]

65. Singh, N.; Nyuur, R.; Richmond, B. Renewable Energy Development as a Driver of Economic Growth: Evidence from Multivariate Panel Data Analysis. Sustainability 2019, 11, 2418. [CrossRef]

66. Alper, A.; Oguz, O. The role of renewable energy consumption in economic growth: Evidence from asymmetric causality. Renew. Sustain. Energy Rev. 2016, 60, 953-959. [CrossRef]

67. Gasparatos, A.; Doll, C.N.H.; Esteban, M.; Ahmed, A.; Olang, T.A. Renewable energy and biodiversity: Implications for transitioning to a Green Economy. Renew. Sustain. Energy Rev. 2017, 70, 161-184. [CrossRef]

68. Inglesi-Lotz, R. The impact of renewable energy consumption to economic growth: A panel data application. Energy Econ. 2016, 53, 58-63. [CrossRef]

69. Yan, Q.; Wan, Y.; Mikalauskas, I.; Mikalauskiene, A. Smart Grids for Renewable Energy: Costs and Benefits. Transform. Bus. Econ. 2017, 16, 430-440. 
70. Chang, M.-C.; Shieh, H.-S. The Relations between Energy Efficiency and GDP in the Baltic Sea Region and Non-Baltic Sea Region. Transform. Bus. Econ. 2017, 16, 235-248.

71. Chen, J.; Cheng, S.; Nikic, V.; Song, M. Quo Vadis? Major Players in Global Coal Consumption and Emissions Reduction. Transform. Bus. Econ. 2018, 17, 112-133.

(c) (

(C) 2019 by the authors. Licensee MDPI, Basel, Switzerland. This article is an open access article distributed under the terms and conditions of the Creative Commons Attribution (CC BY) license (http://creativecommons.org/licenses/by/4.0/). 